\author{
Lassi Heininen ${ }^{1,2 *}$ \\ ${ }^{1}$ International Institute for Applied System Analysis, IIASA \\ 2 University of Lapland, Finland
}

*Corresponding author; lassi.heininen@ulapland.fi

\title{
ARCTIC GEOPOLITICS FROM CLASSICAL TO CRITICAL APPROACH - IMPORTANCE OF IMMATERIAL FACTORS
}

\begin{abstract}
Despite different perceptions, discourses and approaches, the post-Cold War Arctic is with a high geopolitical stability based on institutional, international cooperation started by the Arctic states and supported by Arctic indigenous peoples, nongovernmental organizations and sub-national governments. As a result, there are neither armed conflicts nor serious disputes on national borders. Behind the high geopolitical stability are on the one hand, common interests of the Arctic states to decrease military tension and increase political stability by causing a transformation from confrontation to environmental cooperation. On the other hand, there are certain features of Arctic geopolitics as prerequisites for a transformation, such as firm state sovereignty, high degree of legal certainty, and flexibility in agenda setting. When assessing a state of Arctic geopolitics and IR of the post-Cold War era, there is an ambivalence on how 'geopolitics' is defined. Behind are the dualism of military presence based on the nuclear weapons systems and the high stability based on international, institutional cooperation between the eight Arctic states. As well as, that there are two major competing discourses: first, the Arctic as a 'zone of peace' and exceptional in world politics, and second, that there is a race of resources and the consequent emerging conflicts in the Arctic. In addition, there are fresh reminders that Arctic geopolitics is impacted by (grand) environmental challenges and 'wicked problems', in particular climate change; and that new multidimensional dynamics has made Arctic geopolitics global. The article aims to draw up a holistic picture of the post-Cold War Arctic, and discuss what might be special features of Arctic geopolitics in globalization. The article examines and discusses the transformation of approach from classical geopolitics to critical geopolitics by applying main approaches of geopolitics to the Arctic/Arctic geopolitics.
\end{abstract}

KEY WORDS: Geopolitics, the Arctic, Critical, post-Cold War, World politic

CITATION: Lassi Heininen (2018) Arctic Geopolitics from classical to critical approach importance of immaterial factors. Geography, Environment, Sustainability,

Vol.11, No 1, p. 171-186

DOI-10.24057/2071-9388-2018-11-1-171-186 


\section{INTRODUCTION}

The ultimate aim, or 'arts', of 'Politics' is said to make possible to happen. This requires contest and (political) fight, which is done through, and by, a speech act and rhetoric. They, as well as texts, construct geopolitics, too (Moisio 2003). For example, the phrase to call the Arctic as a "zone of peace" by President Mikhail Gorbachev (1987) has influenced the reality and Arctic geopolitics. There are also other visions or perceptions concerning of the Arctic region, such as "Homeland", "Land of discovery", "Storehouse of resources", "Theater for military", "Environmental linchpin", "Scientific Arctic" by the Arctic Human Development Report (AHDR 2004). Correspondingly, among the imaginaries, or external and internal images, to cross borders are "Terra nullius", "Frozen ocean", "Indigenous statehood", "Resource frontier", "Nature reserve" by Contesting the Arctic (Steinberg et al. 2015). Finally, statements like "What happens in the Arctic, doesn't stay there!", indicate, even manifest, that the Arctic is been globalized (Heininen and Finger, 2017), and the global Arctic has become a barometer for global environmental and climate change.

As an analysis of different perceptions, the Arctic Human Development Report 2004 (Heininen 2004) recognized and defined the following as the main themes/trends of the early-2 $21^{\text {st }}$ century's Arctic geopolitics and IR: increasing circumpolar cooperation by indigenous peoples and sub-national governments; region-building with states as major actors; and a new kind of relations between the Arctic and rest of world. They are still relevant, though the context is been slightly changed, in particular the last one has become more important and strategic.

Popular geopolitics is more than written text. This is seen, when media does not only report about the Arctic but also influence how big audience is reading and interpreting Arctic geopolitics. For example, when a Russian long-range strategic bomber (Tupolev 95 "Bear") is seen flying pass (in international air space), or a military exercise is happening - though the question is about routine patrolling and activities by armies
-, the slogan or headline that "geopolitics is back!" may occur. Or, that in the Arctic there is a'race'for resources and consequent emerging conflicts, as "The Battle for the North Pole" (Traufetter, 2008) media headline indicates. The interpretation of a return of geopolitics, particularly after the Russian expedition to the bottom of the North Pole in 2007, is not only media headlines, wretched slogans or misleading rhetoric. It was/is along to the mainstream interpretation of geopolitics, as well as that of new realism of IR as a traditional understanding of politics, which for example directed the European Union's attention to the Arctic (Raspotnik, 2016). Unlike, indigenous peoples' issues, in particular raised by their organizations, such as identities, land use, self-determination, or knowledge-creation and the interplay between science and politics as responses to security challenges of climate change, are mostly been interpreted to deal with 'governance', not geopolitics. Although dealing with values and aims, and bringing in other actors, they are along to critical approach of geopolitics.

Behind is that at the early-21 ${ }^{\text {st }}$ Arctic geopolitics and international century relations (IR) have been influenced by two major discourses (Heininen, 2010): The dominating discourse says that the Arctic of the early-21 $1^{\text {st }}$ century is with a high geopolitical stability based on established intergovernmental cooperation, the Arctic as a 'zone of peace' (Heininen 2016; Zagorski 2017; Byers 2017; NGP Yearbook 2011, 2012). As a counter-argument, there is another discourse saying that a race of resources and the consequent emerging conflicts, or even a new 'cold war', has started in the Arctic (Borgerson 2008; Traufetter 2008). Further, that the Arctic is like any other region of the world, and therefore it cannot be isolated from international politics (Käpylä and Mikkola 2015). In the literature of Arctic geopolitics \& IR there are several contributions concentrating on the one hand, on different images and perceptions of the Arctic, Arctic governance, Arctic \& Northern indigenous peoples and identities (Raspotnik 2016; Steinberg et al. eds. 2015; Powell and Dodds eds. 2014), and on the other hand, on (state) sovereignty, 
international law and treaties, national policies, institutional points of view and international institutions, such as the Arctic Council (Murray and Nuttall eds. 2014; Yearbook of Polar Law 2013; Heininen 2011). In addition, there are a few fresh reminders: First, that'the environment matters', i.e. Arctic geopolitics, as well as security, is impacted by (grand) environmental challenges, in particular long-range pollution (e.g. nuclear wastes) and rapid climate change (Hoogensen Gjörv et al. eds. 2013). Second, that globalization and its new geo-physical and socio-economic dynamics affect the Arctic region, and followed from that the new multi-dimensional dynamics has made Arctic geopolitics global (Keil and Knecht eds. 2017; Heininen and Southcott, eds. 2010), and the globalized Arctic has worldwide implications to the Earth (System) (Heininen and Finger 2017).

The aim of this article is to draw up a holistic picture of the post-Cold War Arctic, and discuss what might be special features of Arctic geopolitics in globalization. The article examines and discusses the transformation of approach from classical geopolitics to critical geopolitics by applying main approaches of geopolitics to the Arctic/Arctic geopolitics. Before applying geopolitics to the post-Cold War Arctic, I will examine and discuss the main schools of thought of geopolitics and their factors, in particular the approach shift from classical to critical geopolitics.

\section{MATERIALS AND METHODS}

When assessing a state of Arctic geopolitics and IR of the post-Cold War era, there is an ambivalence on how 'geopolitics' is defined, and what approach to use. Behind is the dualism of on the one hand, military presence based on the nuclear weapons' systems of the two superpowers - this is according to classical geopolitics and emphasizing physical space, power, technology and a state -, and on the other hand, high geopolitical stability based on international, institutional cooperation between, and concern on state of the environment by, the eight Arctic states - this indicates critical approach of geopolitics and emphasizes an importance of other factors, such as quality of the environment, knowledge, and that there are several actors. The both parts of the dualism are correct, and thus, facts. Therefore, it is needed to ask: Does the current Arctic geopolitics go along to the mainstream understanding (classical) of geopolitics, or along to critical approach based on the transformation from classical to critical geopolitics? Or, is the current state (of Arctic geopolitics) some sort of hybrid, which includes aspects from the both approach?

To answer to these questions I apply the main schools of thought of geopolitics - classical, new and critical -, and their factors, to the Arctic and Arctic geopolitics of the postCold War period. Here factors (of geopolitics) play important role, as well as who are the actors, in particular important are values and aims of actors, their relations with theories and facts, and in particular how to change the facts to reach the values and aims. Final, I define and discuss common interests between the Arctic states, as well as special features of Arctic geopolitics, which made possible the transformation of the post-Cold War geopolitics from confrontation to high stability.

The used method here is critical approach of geopolitics. It is analytical and goes beyond classical geopolitics and traditional or positivist interpretation of international politics by drawing up a holistic picture on the issue area and having an unorthodox approach of IR. The critical approach, as critical social science in general, aims to take into consideration, in addition of general criteria of science (including criticism), values and aims/goals, and their relations with theories and facts, the interrelations between theories, facts, values and aims/ goals, and final, how to change the facts to reach the values and aims/goals (Harle 2003). This is much according to the original idea of 'politics' to make possible to happen. If you value peace, and aim to have a peaceful situation, you choose theories, methods and means accordingly. Therefore, you cannot lean alone on factors, such as physical space, natural resources and power/force, which are determined with aims/goals like natural laws. You also need actors, in whose interest 
peace is, people(s), civil society and other non-state and non-(security)political elitist actors. Behind is philosophy that to maintain peace is never passive and needs actors with interests, including values and aims to change facts to reach the values.

\section{RESULTS}

Despite different perceptions, discourses and approaches, the post-Cold War Arctic is with a high geopolitical stability based on institutional, international cooperation started by the Arctic states and supported by Arctic non-state actors, such as Arctic indigenous peoples, non-governmental organizations and sub-national governments. As a result, there are neither armed conflicts nor serious disputes on national borders. Instead, there is functional cooperation on several fields, and a dialogue between the Arctic states and other local actors, and between Arctic actors and those from outside of the region. The high stability, as well as cooperation, is firmly stated, even demonstrated, by the eight Arctic states with the first preamble of the joint ministerial meeting declarations of the Arctic Council: "Reaffirming the commitment to maintain peace, stability and constructive cooperation in the Arctic." (e.g., lqaluit Declaration 2015; Fairbanks Declaration 2017), as well as by the five littoral states of the Arctic Ocean (Ilulissat Declaration 2008). The stability seems to have a solid foundation and be resilient, since it has been managed to maintain in spite of recent turbulent times in international politics and uncommon instabilities in world politics, and it has already passed, for far, a few tests (Clifford 2017; Heininen 2016; Heininen et al. 2014).

Behind the high geopolitical stability are on the one hand, common interests of the Arctic states to decrease military tension and increase political stability by causing a transformation from the confrontation of the Cold War period to functional environmental cooperation, and on the other hand, certain features of Arctic geopolitics as prerequisites for a transformation. Though there is a need for further research (Heininen forthcoming), among already known, discussed and analyzed common interests between the Arctic states are): First, to decrease military tension and increase political stability between the former rivals, as the ultimate aim for confidence-building. Second, to start transboundary and functional (expert and scientific) cooperation for environmental protection and assessment, which could be expanded onto other fields. Third, to allow modern region-building with states as major actors, such as the establishment of the Arctic Council. Fourth, to support and encourage circumpolar inter-regional cooperation between Arctic indigenous peoples, sub-national governments and other non-state (local and regional) actors, which will correspondingly support environmental protection and region-building lead by states; Fifth, based on the history of exploration to maintain and enhance the Arctic as a 'laboratory'/'workshop' of international scientific research (Toyama Statement 2016), including to allow the scientific community to reach higher position of influence "within the Arctic Council's subgovernmental policymaking environment than at the domestic level" (Forbis and Hayhoe 2018). Final, to enhance and develop sustainable and long-term business relations and economic development in the Arctic, much prioritized by the Arctic states' national policies and strategies and according to the mission of the Arctic Economic Council.

These common interests and high stability would not be there in the post-Cold War Arctic without a joint understanding within the Arctic states of the value and importance of the high stability, and that the stability built on confidence (which is correspondingly based on cooperation) would be beneficial for all the parties (Heininen 2016; Byers 2017). This understanding, or 'Arctic consensus' (Zagorski 2017), is there even to that extend that there is rational thinking within the Arctic states how much each of them would lose, if anyone of them would damage the cooperation. Behind is 'spillover', the main idea of the process of functional cooperation that as states "become more embedded in an integration process, the benefits of cooperation and the costs of withdrawing from cooperative ventures increase." (Lamy et al. 2013). The short history of the post-Cold War Arctic supports this assertion by the theory of functionalism. 
Correspondingly, before this cooperation started in the Arctic region there were a few features of Arctic geopolitics, as well as those of Arctic security, which can be interpreted to be preconditions for the current state of high geopolitical stability. They made functional cooperation (for environmental protection) possible and promoted the manmade trans-boundary cooperation, and thus also made the transformation possible in the first place. Later they put the Arctic states' governments carefully to consider the risk and costs if they would lose the high stability. Thus, they created opportunities for the Arctic states to recognize common interests and understand the benefits of them, and at the same time these features were strengthened. Among the features as preconditions for international cooperation and high geopolitical are: First, global nuclear deterrence of the two superpowers - the Soviet Union and the USA - as the original nature of the military and a legacy of the Cold War period. Second, that in the Arctic there were/are neither (armed) conflicts nor serious disputes on state sovereignty or disagreements of national borders between the Arctic states. Third, instead there was/is a high degree of international legal certainty in the Arctic, in particular meaning the UNCLOS and the legally-binding agreements under the auspices of the Arctic Council. Fourth, there were devolution and other soft ways of (the Nordic model of) governance, which were renewed and promoted by innovative legal and political arrangements (The Arctic Yearbook 2017; AHDR 2004). Final, the Arctic states have separated issue areas by leaving issues of 'high' politics out of the joint agenda of the Arctic Council (also Byers 2017), in particular that "the Arctic Council should not deal with matters related to military security" (a well-known foot-note in the Ottawa Declaration 1996). As a result, the agenda setting in the post-Cold War Arctic is flexible.

Following the common interests and the geopolitical features as prerequisites, it is possible - as well as there is a need for further research (Heininen forth-coming) to recognize several special features of the post-post Cold War Arctic as potential new themes of Arctic geopolitics of the 2010s. The first special feature is that Arctic geopolitics (consisting of traditional and new several factors of geopolitics), as well as Arctic security (including aspects of traditional, environmental and human security), are tightly connected with the environment. Following from this, geopolitics and security in the Arctic context are combined with each other, as the second feature. The third feature of Arctic geopolitics is 'exceptionalism', i.e. the high geopolitical stability of the post-Cold War Arctic based on the institutional cooperation between the Arctic states, and supported by the Arctic Council observer countries, makes the Arctic region exceptional in world politics and IR. Finally, the Arctic is globalized, and thus, the globalized Arctic can be interpreted as a new geopolitical context, which can be interpreted as a potential asset to reformulate a state of world politics with 'uncommon instability' (Heininen 2016).

\section{DISCUSSION}

\section{From classical to critical geopolitics}

Geopolitics is one of the so-called grand theories used in several disciplines, such as (Political) Geography, Strategic studies and IR. It deals with 'Geography', 'Politics' and 'Technology' with an emphasis on the interrelationships between them. 'Classical geopolitics', the original school of thoughts on geopolitics, as well as its sub-theories, is traditionally interpreted to deal with'physical space,', including natural resources, 'power' and a 'state'. In the focus, are the strategic value and control of a physical space, and the power and hegemony connected with a state (Dougherty and Pfaltzgraff, 1990). Here a 'state' refers to the institution of a nation / unified state as a political and administrative entity, or 'polity', as well as the unified state system. 'Power' means both 'might' of, and brute force by, a state, which is, if needed, guaranteed by "unilateral, national(istic), competitive, military power" (Newcombe 1986). In addition, 'technology' plays a relevant role here, as the technology models of geopolitics did in the Cold War Arctic emphasizing the importance of advanced (arms) technology (e.g., airplane, missile and submarine) (Heininen 1991). 
Among implementations are the abovementioned technology models, which emphasize the strategic importance, even determination of technology. They are interpreted to be the ultimate precondition if advanced military technology allowed it to happen, it happened - for the militarization of the Arctic in the $2^{\text {nd }}$ World War and the Cold War (Heininen 1991). The resources models emphasize the strategic importance of natural resources and potential race and emerging conflicts related to their utilization (Dalby 2002), as the other discourse of Arctic geopolitics states. Final, the so-called "Great Game" vision emphasizes the geostrategic importance of Central Asia very high and followed from this, even as determined, there was the hegemony competition of the major powers in the $19^{\text {th }}$ and $20^{\text {th }}$ centuries and partly still at the early- $21^{\text {st }}$ century.

These models/visions, as well as geopolitics in general, have largely been applied, as well as misused, in politics within the last hundred years. For example, the Nazi Germany used geopolitics, in particular geopolitical thinking interpreted by Friedrich Ratzel and Karl Haushofer, for its power politics and as an excuse to occupy new territories and resources, 'Lebensraum' (Dougherty and Pfaltzgraff 1990). This much ruined the reputation of geopolitics for decades, and was the reason why geopolitics became almost a taboo in science after the $2^{\text {nd }}$ World War. Research on geopolitics was not, however, totally forgotten in the Cold War period, but applied in security and strategic studies, in particular dealing with the maritime strategies of the Soviet Union and the USA in the High North and Arctic waters (e.g. Posen 1987; Miller 1986), as well as arms control and disarmament in the Arctic (Heininen 1991). It was also applied in environmental studies by broadening the scope, for example with an ecological perspective (Dougherty and Pfaltzgraff, 1990). The environment was interpreted to be a geopolitical treat, when states collapse as a result of the explosion of demographic and environmental forces, that the degradation of natural environment causes migration, growth of urban areas, and the consequent disintegration and ethnic conflicts (Kaplan 2002).
Among major (sub)theories of classical geopolitics are the Heartland theory, the Seapower theory and that of Rimland: According to the Heartland theory of Mackinder (e.g. 1904), Russia can be interpreted, or even determined, to control the world, since it controls East Europe and the landmass of Eurasia (the 'Heartland'). It is good to remember that at the time the Arctic Ocean was totally ice-covered and thus, made the huge landmass of Eurasia even bigger. Mahan's Seapower theory (e.g. Mahan 1918) much challenges the Heartland theory and states that who controls, at least, two of the world oceans and has open access into two oceans, controls the world, as did the British Empire and the USA later (interestingly, the Arctic Ocean was neither taken into consideration nor defined as an ocean at the time). Not surprisingly, the USA still much emphasizes the freedom of seas, which is one of the reasons for the USA not to ratify the UNCLOS. Correspondingly, Spykman criticized Mackinder's Heartland theory for overestimating the potential of the Heartland's land mass (Dougherty and Pfaltzgraff 1990), and his Rimland theory (Spykman 1944) emphasizes the strategic importance of the 'Inner Crescent', i.e. the rimland between the heartland and the oceans from the Mediterranian to China. Spykman's theory was a foundation for George Kennan's 'policy of containment' of the Soviet Union, but it has not been applied to the Arctic region consisting of an ocean and two rimlands.

Based on these major theories geopolitics is much to study the spatialization of international politics by major powers and hegemonic states, which understands geopolitics to be concerned "the geography of international politics", especially the relationship between the physical environment and the conduct of foreign policy (Tuathail and Agnew, 1992). Due to the narrow thinking of classical approach, importance of real issues and challenges, such as the environment, people(s) and climate change, were underestimated or neglected. This much sounds like power politics, or what is understood as 'Realpolitik', a traditional understanding of international politics and practice of diplomacy "based 
on the assessment of power, territory, and material interests, with little concern on ethical realities" (Lamy et al. 2013).

Classical geopolitics was challenges in the 1990s by new and critical approaches that re-conceptualized the traditional definitions and interpretations. In the background was on the one hand, that classical geopolitics interpreted geopolitics as a determined dogma. Geopolitics and its traditional interpretations were not deeply analyzed but more copied from natural sciences, as a state "was seen as a living organism that occupies and that grows, contracts, and eventually dies", or at least as an aggregate-organism (Dougherty and Pfaltzgraff 1990). For example, not to consider the Arctic Ocean as an ocean, but only determined by sea ice, does not take into consideration changes in a nature, i.e. climate change, and that those changes, when they are rapid, have societal impacts and influence politics and policymaking. On the other hand, there was a shift in mindset and cultures due to globalization, as well as change in security premises due to pollution and the consequent environmental awakening, and their impacts to policyshaping and policy-making.

Behind were also indicators of a transition into other kinds of more globalized systems, such as economic integration making 'geoeconomics' strategic, regional or city states as new influential actors (with different interests as nation states), and later the social and economic systems based on the digital world developed with the internet (here the internet as a virtual reality can be seen as an emerging geopolitical space (Vuori, 2017)). These approaches made geopolitics a discursive practice by which to represent international politics as a 'world' characterized by particular types of places, peoples and dramas (Tuathail and Agnew, 1992). Geopolitics was (re)defined as human action not determined, since people give the meaning for 'geo' in social and political activities, they are actors, not 'geo' per se. Following from this, geopolitics could also be defined as a contest or fight, where the relation between geopolitical discourse and geopolitical rhetoric is important (Moisio, 2003).
All in all, redefinition of geopolitics occupied more room with new discourses, and 'new' and 'critical'schools of thought of geopolitics were established. It was the 1990s, when geopolitics had some sort of renaissance in research. For example, 'new geopolitics' as a school of thoughts is keenly related with the growing importance of 'Economics' per se, and economic integration, when after the end of the Cold War period economics took over geopolitics (Ohmae, 1995). Economic integration became more important in international politics and foreign policy, when national economies were not any more strictly regulated by states, influenced by new theories of economics, such as 'New liberalism', but opened for international markets run by trans-national financial and other companies.

The importance of geoeconomics could also be seen in the 1990s among the Arctic states, when after the end of the Cold War the Nordic countries, first joined the European Economic Area (EEA) in 1994, and in 1995 Finland and Sweden joined the ECs / EU (Denmark had joined in 1973). As well as, when Canada and the USA, together with Mexico, established the North America Free Trade Area (NAFTA) in 1996. Or, when the Arctic states showed more interest towards economic activities in the Arctic by establishing joint ventures between Western and Russian companies dealing with exploitation of hydrocarbons in the Russian Arctic, and thus going beyond the geopolitical barriers of the Cold War. For example, there were several negotiations between Russian companies (e.g. Gazprom, Rosneft) and Western companies (e.g. Norsk Hydro, Conoco Inc., Total S.A., Neste Oy) about joint exploitation of oil and gas drilling ventures. The best known of them the Shtokman gas field "became a flagship name for Russian oil and gas development in offshore Arctic conditions. "This flagship status was related to the desire of the state to find new sources of economic stability..." (Goes, 2018). So, when internationally the Shtokman case was seen from the point of view of geoeconomics and a part of new liberalism, nationally in Russia it, was seen as a strategic resource base which 
provides the means for the socio-economic development of the country.

These new discourses and approaches challenged, as well as problematized, the traditional approaches of geopolitics by having a general understanding that, in addition of physical space, technology and state power, there exit other factors, which deal with values, aims/goals and other immaterial things, as well as interrelations between different factors. Among them are 'social space', 'identity/ies' and 'knowledge', which come together with people(s), indicating that there are other actors as a state (Moisio 2003; Jukarainen 1999). As well as 'cooperation' and 'peace' as means how to change the existing facts and reach your aims. As a result, in addition of more traditional factors, new (immaterial and soft) factors, as well as new actors, were also recognized relevant to geopolitics, and that they - i.e. values and aims, their relations with theories and facts and their interrelations - should be taken into consideration, in particular how to change the facts to reach the values and aims.

\section{Recent changes of Arctic geopolitics}

Based on classical approach of geopolitics (e.g., the technology and resources models, etc..) and its major factors (e.g., physical space, power connected with a state) for the Arctic states - either the eight Arctic states (A8), or the five littoral states of the Arctic Ocean (A5) - sovereignty, power over resources and resource governance, and economic interests are still important. They do, however, also take into consideration fundamental changes in the Arctic and Arctic geopolitics due to globalization and global impacts, such as climate change, within the Arctic region. Indeed, climate change, and long-range pollution earlier, have clearly shown, even manifested, the strategic importance of the environment, and that it has become an important (new) geopolitical factor as a value with aims to change it (either via mitigation or adaptation) (Heininen 2013). One of the weaknesses of the traditional approach of geopolitics is a lack to recognize the environment as a value, and that quality

Table 1. Differences between 'Classical' and 'Critical' Geopolitics and Their Factors

\begin{tabular}{|l|l|}
\hline 'Classical' geopolitics: & 'Critical' geopolitics: \\
\hline $\begin{array}{l}\text { Traditional and narrow interpretation of } \\
\text { 'Geo' +'Politics'; }\end{array}$ & $\begin{array}{l}\text { Goes beyond 'Realpolitik' and challenges } \\
\text { mainstream thinking; }\end{array}$ \\
$\begin{array}{l}\text { Reflects exploration, state sovereignty, } \\
\text { hegemony and force; }\end{array}$ & $\begin{array}{l}\text { Reflects sophisticated power and } \\
\text { recognizes knowledge as power; } \\
\text { Factors: in addition those of classical } \\
\text { Factors: physical space + natural resources } \\
\text { technology, power/force by the state (e.g. } \\
\text { the Resource models and Technology } \\
\text { models) }\end{array}$ \\
$\begin{array}{l}\text { 'politicization' of physical space (the } \\
\text { environment), and in addition of the state } \\
\text { several actors (including people(s) and civil } \\
12 \text { times of 16 a war has occurred when a } \\
\text { rising power defeat (Allison, 2017). }\end{array}$ & $\begin{array}{l}\text { society). } \\
\text { From classical geopolitics to critical } \\
\text { geopolitics indicates and reflects the } \\
\text { movement from determined, disciplinary } \\
\text { theories towards different discourses and } \\
\text { interpretations ('politicization' of physical } \\
\text { space), from power politics to knowledge } \\
\text { (wicked problems), from centralized to } \\
\text { subsidiarity (devolution), from national } \\
\text { to local and global (globalism), and from } \\
\text { material to immaterial (digitalization). }\end{array}$ \\
\hline
\end{tabular}


(of the environment) matters, in addition of interpreting the environment only as physical space with natural resources. The irony here is that geopolitics is defined as one of the major environmental theories (Dougherty and Pfaltzgraff 1990).

Unlike, critical geopolitics recognizes new factors, such as identities, knowledge, stability, as well as takes into consideration other actors, indigenous and other peoples, civil societies and sub-national governments, as well as their interests, are in focus. Based on that it is needed to have a more holistic and multi-dimensional approach and solid description of the twenty-first century's globalized Arctic region. Further, the multidimensional and multi-functional nature of Arctic geopolitics includes, for example, that there are more sophisticated factors and several actors with their identities have taken into consideration. Further, that identity matters and much deals with livelihoods, and that pollution impacts heavily and kills thousands, and that climate change threatens peoples' traditional livelihoods. This approach refers to critical geopolitics including the following aspects: first, to take into consideration rapid climate change and long-range pollution which together with an increase in extractive industries create a real wicked problem in the Arctic; second, based on the COP 21 Paris Agreement and the related pressure to reduce $\mathrm{CO}_{2}$ emissions, freeze new investments in (offshore) oil and gas drilling (e.g. Shell's decision to withdraw from the Beaufort Sea) and develop renewable energy resources in the Arctic; third, to (re)define who are relevant (international) actors and stakeholders in Arctic geopolitics and regional (resource) development, and in particular what is the position of the Arctic states and state-related actors there.

Controversial or not, those traditional factors of geopolitics - physical space, natural resources, technology and power of a state - are still present and relevant in the Arctic and Arctic geopolitics: The Arctic is a geographical region with a unique ecosystem, large marine nature and ice covered seas. The Arctic is (still) interpreted as a resource storehouse due to its rich natural resources, such as hydrocarbons and other minerals (USGS 2008), fishes and other marine animals, forests. Though it might sound as a cliché, this is the de facto reason for mass-scale utilization of resources, and that resource exploitation has been emphasized in the national strategies and policies of all Arctic states. Following from this, it is justified to argue that the resource models are still relevant and applied in the Arctic. The technology models are also relevant, though not emphasized in the national strategies. The heavy military structures, mostly nuclear weapon systems of Russia and the USA, are deployed in the region due to their global deterrence (Wezeman 2012), which is also a reason for no real nuclear disarmament, yet, in the Arctic.

Unlike, critical geopolitics recognizes several factors, and that there are several actors, which influence Arctic geopolitics. One of the new factors is an 'actor' per se, i.e. the fact that there are other actors as a/the 'state', people(s) and civil societies, and Indigenous peoples without their own state (Abele and Rodon 2007). The agent-based modeling emphasizes the importance of actors but forgets the importance of their interests, though actors always come with interests, and interests much deal with values. Indeed, the post-Cold War Arctic geopolitics is influenced by an increasingly dense network of transnational actors, including Indigenous peoples (organizations) energetically emphasizing their cultural and political identities and redefining sovereignty (Inuit Declaration 2009), subnational governments in charge of regional development seeking collaboration both within and beyond national borders, NGOs with concerns and ambitions to shape the discourse, and academic communities producing knowledge, thus shaping our understanding of the region.

Closely related with (Indigenous) peoples and civil societies (geographical) knowledge is a format of power, which is relevant, and should take into consideration (Moisio, 2003). The more critical factor climate change, in particular its global nature, has become, the more important format 
of power, or influence, knowledge on climate and the environment has become. Therefore, in Arctic research traditional or indigenous environmental knowledge (TEK) has already some time been recognized by Western science (Toyama Statement, 2016; Agreement of Science Cooperation, 2017).

Following from this, power does not, any more, mean only 'hard' power, political or economic power and military force, and more importantly, there is influence, which can be transferred into power. Though the air is, every-now-and-then, full of misand disinformation, conspiracy theories, manipulation and falsification, and these are not only phenomena of the era of the internet and social media, power based on influence is more based on knowledge and communications. Finally, to have identity, knowledge and other immaterial values as geopolitical factors, as well as indigenous peoples as actors, there is a growing concern on a state (quality) of the environment and that of climate. As critical approaches of geopolitics, this means to politicize a physical space. Indeed, the post-Cold War Arctic is been highly politicized, though not re-militarized, by more soft and sophisticated ways than was the militarization in the Cold War.

If in the $2^{\text {nd }}$ WW geopolitics was misused, in the Arctic of the 2010s it is often misunderstood, in particular in media reports and also by policy-makers, and understood narrowly to mean traditional approach (classical) geopolitics. Fortunately, so far this has come with less harmful consequences causing mostly misinformation and confusion, though it has put the established international Arctic cooperation into a test. Actually, geopolitics influences, or the influence is seen in, the post-Cold War Arctic by several and different ways: from the presence of the nuclear weapon systems (as a legacy of classical geopolitics of the Cold War), and an emphasis on sovereignty by the littoral states of the Arctic Ocean (as a legacy of state and state power) to responses of non-state actors on a state of the environment (as an example of politicization of the Arctic region) and those of governments to new security threats (as an evidence of a shift in security premises) due to impacts of long-range pollution and global warming, as well as to growing global

Table 2. Major Stages of Arctic Geopolitics

\begin{tabular}{|c|c|c|}
\hline Cold War's geopolitics: & $\begin{array}{l}\text { Transition period's } \\
\text { (1980s-1990s) geopolitics: }\end{array}$ & Post-Cold War's geopolitics: \\
\hline $\begin{array}{l}\text { Dominated by militarization: } \\
\text { the military (the nuclear } \\
\text { weapon systems); } \\
\text { technology, state hegemony } \\
\text { and power game = } \\
\text { mostly based on classical } \\
\text { geopolitics. }\end{array}$ & $\begin{array}{l}\text { Dominated by } \\
\text { environmental degradation } \\
\text { and transboundary } \\
\text { cooperation: long-range } \\
\text { pollution, nuclear accidents } \\
\text { and growing concern } \\
\text { on the environment; } \\
\text { international cooperation } \\
\text { on environmental } \\
\text { protection and research; } \\
\text { self-consciousness and } \\
\text { circumpolar cooperation by } \\
\text { Indigenous peoples = based } \\
\text { on new and more critical } \\
\text { approaches of geopolitics. }\end{array}$ & $\begin{array}{l}\text { Dominated by climate } \\
\text { change and hype of } \\
\text { exploitation: pollution } \\
\text { \& rapid climate change } \\
\text { (e.g. food safety); hype of } \\
\text { mass-scale exploitation } \\
\text { and increase of economic } \\
\text { activities ('geoeconomics'); } \\
\text { importance of state } \\
\text { sovereignty and energy } \\
\text { security; high geopolitical } \\
\text { stability and firm } \\
\text { transboundary cooperation } \\
\text { (exceptional); scientific and } \\
\text { traditional knowledge (on } \\
\text { climate and environment) } \\
\text { as a new format of power = } \\
\text { based on critical geopolitics } \\
\text { and globalism. }\end{array}$ \\
\hline
\end{tabular}


interest towards, and influence in, the Arctic (as critical approaches of geopolitics).

In contrast to traditional approach, a comprehensive description with holistic approach of the twenty-first century's Arctic geopolitics includes comprehensive coverage of the approaches of both classical (Cold war) and critical (post-Cold war) geopolitics, i.e. "the history and identity of a 'geopolitical' Arctic and the contemporary triangle of Arctic geopolitics: rights, interests and responsibilities" (Raspotnik, 2016). For example, to (re)place the Arctic within the context of global multi-dimensional change, and explore worldwide implications would give a chance to define the global Arctic as a new geopolitical context. A state of Arctic geopolitics at the post-Cold War era is much with this kind of comprehensive approach including identities, rights and responsibilities, as well as (traditional) knowledge and stability-building (Heininen 2016).

\section{CONCLUSIONS}

At the early- $21^{\text {st }}$ century the Arctic region plays a key role in the global ecosystem and bio-geophysical processes that are heavily impacted by climate change and other global changes, and are closely integrated with current global economics and related energy security dynamics, as they relate to world politics. Long-range pollution was the first trigger, which caused a change in security premises and a paradigm shift, and made environmental protection as the first field of functional cooperation between the eight Arctic states. It was followed by the rapid warming of Arctic climate. These were wake-up calls to the Arctic states of growing concern on a state of the environment by non-state actors, such as indigenous peoples, (I)NGOs, scientists and scholars to start environmental cooperation. These were behind the first special feature of Arctic geopolitics from the point of view of critical approach of geopolitics.

Followed from the functional cooperation for environmental protection by the Arctic states, there was a significant change in
Arctic geopolitics from the confrontation of the Cold War period to transboundary cooperation at the $21^{\text {st }}$ century. Due to this institutionalized Arctic cooperation there is high geopolitical stability and the region is neither overtly plagued by military conflicts nor disarmament, though the nuclear weapon systems of Russia and the USA are still been deployed there. International Arctic cooperation, under the auspices of the Arctic Council and between the Arctic states and the Arctic Council observer countries continues, so far, after passing a few tests of growing tension between Russia and the West, as well as the consequent sanctions and counter-sanctions. This exceptionalism is another special feature of Arctic geopolitics (from the point of view of critical approach of geopolitics).

Behind are on the one hand, common interests starting from the ultimate aim to decrease military tension and increase political stability using functional cooperation on environmental protection, due to pollution (in particular nuclear safety), and region-building as the main means. On the other hand, certain features of the Arctic were prerequisites for stability-building, such as the original global nature of the military, firm state sovereignty, high degree of legal certainty, and separation of certain issue areas, in particular that military-security, on the agenda of the Arctic Council. Followed from this, first conclusion of this article is that the high Arctic geopolitical stability is conscious and manmade (by the Arctic states). It also seems to be resilient, since it has passed a few tests, and big geopolitical changes, such as the self-governing status of Greenland, could be executed in a calm and peaceful manner with full agreement of a state and sub-national government.

Another conclusion, as well as a scientific finding, is that based on the common interests and the preconditions there are certain (existing or emerging) features of Arctic geopolitics: First, that geopolitics and security are tightly connected with the environment, and second that geopolitics and security are been combined with each other in the Arctic context. The third feature of Arctic geopolitics is that the Arctic is 
globalized. The final one is that the high geopolitical stability, as a common interest of the Arctic states and their joint efforts to maintain it, makes the globalized, stable Arctic region exceptional in world politics and IR. This can been interpreted as a potential asset to (re)formulate world politics of turbulent times and with 'uncommon instability' and IR. These special features can be interpreted as new themes, or trends, of the post-post Cold War's Arctic geopolitics. When to interpret them as trends, there is an opportunity for a paradigm shift in approaches of geopolitics, if to aim to change the facts in order to reach the values, i.e. how to understand politics and power and make peaceful transformation to happen.

\section{REFERENCES}

Abele F. and Rodon T. (2007)."Inuit Diplomacy in the Global Era:The Strengths of Multilateral Internationalism." Canadian Foreign Policy, (13)3 (2007), pp. 45-63.

Ackren M. (2014). "Greenlandic Paradiplomatic Relations." Security and Sovereignty in the North Atlantic. Basingstoke: Palgrave Macmillan, Palgrave Pivot, 42-61.

AHDR (2004). Arctic Human Development Report, AHDR 2004. Akureyri: Stefansson Arctic Institute.

The Agreement on Enhancing International Arctic Scientific Cooperation (2017). Signed on 11 May 2017 by the Arctic States.

Allison G. (2017). High stakes: Can Trump and Xi avoid war and strike a North Korea deal? TIME, April 17, 2017, pp. 8-9.

The Arctic Yearbook 2017 - "Change and Innovation in the Arctic: Policy, Society \& Environment." Eds. by L. Heininen, H. Exner-Pirot \& J. Plouffe. [online] Thematic Network on Geopolitics and Security, and Northern Research Forum. Available at: http://www. arcticyearbook.com

The Arctic Yearbook 2015 "Arctic Governance and Governing." Eds. by L. Heininen, H. ExnerPirot and J. Plouffe. [online] Thematic Network on Geopolitics and Security, and Northern Research Forum. Available at: http://www.arcticyearbook.com

Borgerson S.G. (2008). "Arctic Meltdown: The Economic and Security Implications of Global Warming". Foreign Affairs, March/April 2008.

Byers M. (2017). Crises and international cooperation: an Arctic case study. International Relations 2017, Vol. 31(4) 375-402.

Byers M. (2013). International Law and the Arctic. Cambridge, UK: Cambridge Studies in International and Comparative Law.

Clifford R. (2017). How has cooperation in the Arctic survived Western-Russian geopolitical tension? Available at: http://pagebuilder.arctic.arcpublishing.com/pb/voices/ analysis/2017/01/04/how-has-cooperation-in-the-arctic-survived-western-russiangeopolitical-tension/

Dalby S. (2002). "Environmental Security." Borderlines, Volume 20. Minneapolis: University of Minnesota Press.

Dougherty J.E. and Pfaltzgraff R.L. Jr. (1990). Contending Theories of International Relations. A Comprehensive Survey. Third Edition. USA: Harper Collins Publishers. 
Fairbanks Declaration (2017). Fairbanks Declaration On the Occasion of the Tenth Ministerial Meeting of the Arctic Council. (mimeo)

Forbis R.Jr. and Hayhoe K. (2018). "Does Arctic Governance hold the key to achieving climate policy targets?"Environmental Research Letters 13 [online] (2018) 020201 Available at: https://doi.org/10.1088/1748-9326/aaa359

Goes M. (2018). An interview in a phone by L. Heininen in 8 March 2018. Personal notes.

Gorbachev M. (1987). The Speech in Murmansk at the ceremonial meeting of the occasion of the presentation of the Order of Lenin and the Glod Star Medal to the city of Murmansk, October 1, 1987. Moscow: Novosti Press Agency.

Harle V. (2003). “Onko kriittinen geopolitiikka kriittistä tiedettä? Muuttuva geopolitikka. Eds. by V. Harle and S. Moisio. Tampere: Gaudeamus, pp. 17-35.

Heininen L. (forth-coming). "Special Features of Arctic Geopolitics - a potential asset for world politics?" GlobalArctic Handbook. Eds. by M. Finger \& L. Heininen. Springer. (will be published in autumn 2018)

Heininen L. (2016). "Security of the Global Arctic in Transformation - Changes in Problem Definition of Security". Future Security of the Global Arctic. State Policy, Economic Security and Climate. Ed. by Lassi Heininen. Basingstoke: Palgrave Macmillan, Palgrave Pivot, 2016, pp. 12-34.

Heininen L. (2014)."Northern Geopolitics: Actors, Interests and Processes in the circumpolar Arctic." Polar Geopolitics: Knowledges, Resources and Legal Regimes. Edited by Richard C. Powell and Klaus Dodds. Edward Elgar: Cheltenham, UK and Northampton, Massachusetts, 2014, pp. 241-258.

Heininen L. (2013). "'Politicization' of the Environment: Environmental Politics and Security in the Circumpolar North." The Fast-Changing Arctic: Rethinking Arctic Security for a warmer World. Edited by Barry Scott Zellen. Calgary: University of Calgary Press, pp. 35-55.

Heininen, L. (2011). "Arctic Strategies and Policies - Inventory and Comparative Study." Akureyri: The Northern Research Forum \& The University of Lapland. August 2011.

Heininen L. (2010). "Pohjoiset alueet muutoksessa - geopoliittinen näkökulma (The High North in a Change - Geopolitical point of view)." Politiikka 1 / 2010, pp. 5-19.

Heininen L. (2004). "Circumpolar International Relations and Geopolitics." In: AHDR (Arctic Human Development Report) 2004. Akureyri: Stefansson Arctic Institute, pp. 207-225.

Heininen L. (1991). "Sotilaallisen läsnäolon ympäristöriskit Arktiksessa - Kohti Arktiksen säätelyjärjestelmää." Tampere Peace Research Institute. Research Report No. 43. Tampere: Tampereen yliopisto.

Heininen L. and Finger M. (2017). "The 'Global Arctic' as a New Geopolitical Context and Method." Journal of Borderlands Studies, 2017. [online] Available at: https://doi.org/10.108 0/08865655.2017.1315605 (downloaded at 05:37 04 December 2017)

Heininen L. and Southcott C., ed. (2010). The Circumpolar North and Globalization. Fairbanks: University of Alaska Press. 
Heininen L., Sergunin A. and Yarovoy G. (2014). "Russian Strategies in the Arctic: Avoiding a New Cold War."The Valdai Discussion Club, Grantees Report. Moscow, Russia, September 2014. Available at: www.valdaiclub.com. Accessed on 22nd of October 2014.

Hoogensen Gjörv G., Bazely D.R., Goloviznina M. and Tanentzap A.J., eds. (2013). Environmental and Human Security in the Arctic. Tonbridge, Kent: Routledge and Eartscan from Routledge.

Inuit Declaration (2009). A Circumpolar Inuit Declaration on Sovereignty in the Arctic." adopted by the Inuit Circumpolar Council.

The Ilulissat Declaration (2008). Arctic Ocean Conference - Ilulissat, Greenland, 27-29 May 2008. (mimeo)

Iqaluit Declaration (2015). On the occasion of the Ninth Ministerial Meeting of the Arctic Council. Iqaluit, Canada, 24 April 20015. (mimeo)

Jukarainen P. (1999). "Norden is Dead - Long Live the Eastwards Faced Euro-North. Geopolitical Re-making of Norden in a Nordic Journal." Cooperation and Conflict, vol. 34(4), pp. 355-382. SAGE Publications.

Kaplan R.D. (2002). The Coming Anarchy. Shattering the Dreams of the Post Cold War. USA: Random House.

Keil K. and Knecht S., ed. (2017). Governing Arctic Change. Global Perspectives. London: Palgrave Macmillan.

Käpylä J. and Mikkola H. (2015). On Arctic Exceptionalism. Critical reflections in the light of the Arctic Sunrise case and the crisis in Ukraine. The Finnish Institute of International Affars, FIIA Working Paper, April 2015.

Lamy S.L., Baylis J., Smith S., Owens P. (2013). Introduction to Global Politics. New York, Oxford: Oxford University Press. Second Edition.

Mackinder H.J. (1904). The Geographical Pivot of History. The Geographical Journal, Vol. XXIII. No. 4, April 1904, pp. 421-444.

Mahan A.T. (1918). The Influence of Sea Power upon History 1660-1783. Boston.

Miller S. (1986). The Maritime Strategy and Geopolitics in the High North. September 1986. (mimeo)

Moisio S. (2003). "Geopolitiikka kamppailuna". Muuttuva geopolitikka. Eds. by V. Harle \& S. Moisio. Tampere: Gaudeamus, pp. 93-109.

Murray R.W. and Nuttall A.D., ed. (2014). International Relations and the Arctic. Understanding Policy and Governance. Amherst, New York: Cambria Press.

Newcombe H. (1986). "Collective Security, Common Security and Alternative Security: A Conceptual Comparison." Peace Research Reviews, 10(3), pp. 1-8, 95-99.

NGP Yearbook 2011, "Sustainable Development in the Arctic region though peace and stability" (2012). Nordia Geographical Publications, Volume 40: 4.2012. Tornio: Geographical Society of Northern Finland.

Ohmae K. (1995). The End of the Nation State. The Rise of Regional Economics. New York: The Free Press. 
Ottawa Declaration (1996). Declaration on the Establishment of the Arctic Council. Ottawa, Canada - September 19, 1996. (mimeo)

Posen B. (1987). U.S. Maritime Strategy: a dangerous game. Bulletin of Atomic Scientists, Vol. 43. No. 7, September 1987, pp. 24-29.

Powell R.C. and Dodds K., ed. (2014) Polar Geopolitics: Knowledges, Resources and Legal Regimes. Cheltenham, UK and Northampton, Massachusetts: Edward Elgar.

Raspotnik A. (2016). The European Union and its Northern Frontier: European Geopolitics and its Arctic Context. PhD. Universität zu Köln, Deutscland.

Spykman N.J. (1938). Geography and Foreign Policy I. The American Political Science Review, Vol. 32, Issue 1.

Spykman N.J. (1944). The Geography of Peace. New York.

Steinberg P.E., Tasch J. and Gerhardt H., ed. (2015). Contesting the Arctic, Politics and imaginaries in the Circumpolar North. London: I.B. Tauris Publishers.

Toyama Conference Statement (2015). Integrating Arctic Research: A Roadmap for the Future. ASSW 2015 in Toyama, 30 April 2015. (mimeo)

Traufetter G. (2008). The Battle for the North Pole. Melting Ice Brings Competition for Resources. Der Spiegel, 19 September 2008.

Tuathail G.O. and Agnew J. (1992). "Geopolitics and discourse: practical geopolitical reasoning in American foreign policy." Political Geography, Volume 11, Issue 2, March 1992, pp. 190-204.

USGS (2008). 'Circum-Arctic Resource Appraisal: Estimates of Undiscovered Oil and Gas North of the Arctic Circle.' US Geological Survey Fact Sheet 2008-3049. July 2008, http:// www.eurasiareview.com

Vuori A. (2017). "The emerging political space of the internet: Geopolitics in the digital world." Research Plan for a PhD studies (September 2017). University of Lapland. (mimeo)

Wezeman S.T. (2012). Military Capabilities in the Arctic. SIPRI Background Paper, March 2012.

The Yearbook of Polar Law Volume 5, 2013 (2013). Edited by G. Alfredsson, T. Koivurova and A. Stepien. Leiden-Boston: Martinus Nijhoff Publishers.

Zagorski A. (2017). "Arctic Consensus." The Arctic Herald, Information \& Analytical Journal, 1(20). 2017, pp. 42-47. 


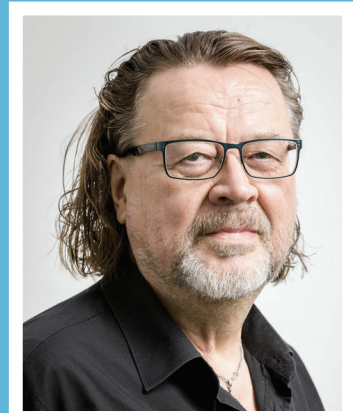

Dr. Lassi Heininen is a Professor of Arctic Politics at University of Lapland (Finland) and Senior Research Scholar (associate) at IIASA (Austria). His research fields include IR, Geopolitics, Security Studies, Environmental Politics, Arctic Studies. Prof. Heininen teaches and lectures regularly abroad, and supervises MA and $\mathrm{PhD}$ students from different countries. Among his other recent academic positions are Visiting Professor at University of Akureyri (Iceland), Adjunct Professor at Trent University (Canada), Director of International Summer School in Karelia at Petrozavodsk State University (Russia), Holder of Foreign Experts Professorship at Tongji University (China). He is also Head of (UArctic-NRF) Thematic Network on Geopolitics and Security. 